\title{
CENCO, INC. V. SEIDMAN \& SEIDMAN: A FUTILE ATTEMPT TO DETER MANAGEMENT FRAUD
}

Contemporary corporations suffer from unparalleled instances of employees using their positions in the corporation for personal gain. ${ }^{1}$ Top-level managers, in particular, can use their positions in the corporation for personal gam; 2 managers can conceal large-scale frauds more easily than low-level employees can, because of their ability to manipulate internal controls. ${ }^{3}$ Not surprisingly, independent accountants hired by a corporation frequently fail to discover such management fraud. ${ }^{4}$

1. According to one "conservative" estimate, employee theft costs businesses approximately $\$ 41.8$ billion per year. See Kantor, How to Foil Employe [sic] Crime, Natron's Bus., July 1983, at 38. In fact, a business may lose as much as a third of its profits to internal theft. Id. Inside theft may also account for $30 \%$ of all business failures. Id ; see also R. HoLIINGER \& J. CLARK, THEFT BY EMPLOYEES 2-4 (1983)(employee theft increases prices by twelve cents on the dollar).

2. According to one authority, it is impossible to determine the average losses to shareholders and others from management fraud; several cases involve losses of $\$ 100$ million to $\$ 200$ million to shareholders alone. W. Albrecht, M. Romney, D. Cherrington, I. Payne \& A. Roe, How to Detect and Prevent Business Fraud 24 (1982).

3. One of the "basic concepts" of auditing is that

[t]he establishment and maintenance of a system of internal control is an important responsibility of management. The basic concepts implicit in the definition of accounting control are discussed in the context of that responsibility. The system of internal control should be under contimuing supervision by management to determine that it is functioning as prescribed and is modified as appropriate for clianges in conditions.

1 AICPA PRofessional Standards (CCH) AU \& 320.31 (1972).

4. Under the federal securities laws an annual audit is mandatory for most publicly held corporations. The Securities Act of 1933 and the Securities Exchange Act of 1934 require independent auditors to certify certain financial statements rcleased by such corporations. See Securities Act of 1933, 15 U.S.C. $\$ \$ 77 \mathrm{aa}$, schedule A, itens 25-27, 77sa (1982); Securities Exchange Act of 1934, 15 U.S.C. $\$ \S 78(l)(b)(1)(J), 78(l)(b)(1)(K), 78 \ln (a), 78 \ln (b)(1982)$.

Although auditors should be aware of the possibility of managenent fraud, their audits will not necessarily discover such fraud. See 1 AICPa Professional Standards (CCH) AU $\$ 327.09$ (1977); M. Epstein \& E. Weiss, A Practical Guide to Accountants' Legal LIABILITY 14-15 (1977). Some forms of management fraud are virtually undetectable because of the "inherent limitations" of the auditing process. See 1 AICPA Professional Standards (CCH) AU \& 327.11 (1977). The cost of an audit should bear a reasonable relationship to the benefits expected to be derived from it. Id. Therefore, selective testing of the data being examined "is subject to the inherent risk that material errors or irregularities, if they exist, will not be detected." Id.

The auditor should, however, recognize that management can direct subordinates to conceal or misrepresent information that could result in a material misstatement of the financial statements. Id. \$327.09 (1977). Because "management can perpetrate irregularities by other employees. . . the auditor should be aware of the importance of management's integrity to the effective operation of internal accounting control procedures and should consider whether there 
When defrauding managers successfully avoid detection by independent auditors, injured shareholders may sue the auditors for damages caused by the management fraud. 5 In such suits, the auditors usually argue that the corporation should bear legal responsibility for the fraud. Traditionally, courts analyzing legal responsibility for employee fraud use principles of state contract or tort law. ${ }^{6}$ In Cenco, Inc. v. Seidman \& Seidman ${ }^{7}$ the United States Court of Appeals for the Seventh Circuit refused to use the traditional approach to determine

are circumstances that might predispose management to misstate financial statements." Id, see also id. $\$ 327.10$ (1977)(factors to consider in determining whether management may have overridden control mechanisms).

In addition to management override of internal controls, "[c]ertain acts, such as collusion. . . among management . . . may result in misrepresentations being made to the auditor . . . that appear truthful and genuine." $I d . \$ 327.12$ (1977). The auditor's reliance on the truthfulness of certain representations is reasonable. Id. The auditor is "not an insurer or guarantor; if his examination was made in accordance with generally accepted auditing standards, he has fulfilled his professional responsibility." Id. \& 327.13 (1977). For a discussion of a corporation's mternal accounting control system, its importance in the reliability of financial statements, and what constitutes "reasonable assurance" that the system works, see Ad Hoc Committee on Reports by Management, Reports by Management: A Discussion Paper, 36 Bus. LAw 1061, 1067-69 (1981).

5. See, e.g., Schacht v. Brown, 711 F.2d 1343, 1360 (7th Cir.), cert. denied, 104 S. Ct. 508, 509 (1983); Cenco, Inc. v. Seidman \& Seidman, 686 F.2d 449, 457 (7th Cir.), cert. denied, 103 S. Ct. 177 (1982).

6. Origmally, courts expressed a reluctance to hold accountants responsible for undetected employee fraud under any principle of law. See, e.g., City of E. Grand Forks v. Steele, 121 Minn. 296, 299-300, 141 N.W. 181, 182 (1913)(damages too remote); National Sur. Corp. v. Lybrand, 256 A.D. 226, 236, 9 N.Y.S.2d 554, 563 (1939)(although plaintiff established a prima facie case of negligence, the jury determines whether the accountants could have anticipated losses incurred after their audit); Craig v. Anyon, 212 A.D. 55, 64-65, 208 N.Y.S. 259, 267-68 (contributory negligence a defense and danıages too remote), affd without opinion, 242 N.Y. 569, 152 N.E. 431 (1925); O'Neill v. Atlas Auto. Fin. Corp., 139 Pa. Super. 346, 350, 11 A.2d 782, 784 (1940)(accountants' examination is a limited contractual undertaking and therefore no liability for failure to discover embezzlement). Concern that the potential damages would be prohibitive has caused most of this reluctance. See M. EpSTEIN \& E. Weiss, supra note 4, at 12, 22. Accordingly, some of the earlier decisions insisted on an action for breach of contract rather than in tort, because of the assumption that damages would be more restrictive in the former cause of action. See, e.g., Steele, 121 Minn. at 300, 141 N.W. at 182;Anyon, 212 A.D. at 66, 208 N.Y.S. at 268; see also Hawkins, Professional Negligence Liability of Public Accountants, 12 VAND. L. REv. 797, 800 (1959). Courts eventually recognized that accountants are commonly hired for the very purpose of detecting employee fraud, see, e.g., National Sur. Corp. v. Lybrand, 256 A.D. 226, 235-36, 9 N.Y.S.2d 554, 562-63 (1939), and consequently now allow recovery for breach of contract or in tort for negligeut action. See Maryland Casualty Co. v. Cook, 35 F. Supp. 160, 165 (E.D. Mich. 1940); Dantzler Lumber \& Export Co. v. Columbia Gas Co., 115 Fla. 541, 548, 156 So. 116,118 (1934); Lybrand, 256 A.D. at 234-36, 9 N.Y.S.2d at 561-63. These alternative bases for recovery reflect the corporation's expectation that the audit will be performed with reasonable care and competence and in accordance with professional standards, see Gammel v. Ernst \& Ernst, 245 Minn. 249, 250-51, 72 N.W.2d 364, 367-68 (1955); Katsoris, Accountants' Third Party LiabilityHow Far Do We Go?, 36 FordHAM L. REv. 191, 192 (1967), as well as the contractual origin of the employment relationship, see Southern Methodist Univ. v. United States, 645 F.2d 893, 900 (Ct. Cl. 1981).

7. 686 F.2d 449 (7th Cir.), cert. denied, 103 S. Ct. 177 (1982). 
accountant liability for management fraud that was not discovered by an audit. Instead, the court's opinion, written by Judge Posner, utilized "economic analysis" to determine the appropriate law. ${ }^{8}$

This note examines the effectiveness of the Cenco court's attempt to reach an economically efficient result. The note begims by presentimg the facts and the court's reasoning in Cenco. ${ }^{9}$ It then analyzes the deficiencies in the court's analysis. ${ }^{10}$ The note concludes that the holding in Cenco will not deter management fraud, primarily because it fails to take imto account the propriety of the auditor's actions. ${ }^{11}$

\section{CENCO, INC. v. SEIDMAN \& SEIDMAN: MANAGEMENT FraUd AS AN ACCOUNTANT's DEFENSE}

In Cenco, Inc. v. Seidman \& Seidman the Court of Appeals for the Seventh Circuit upheld a jury instruction that permitted accountants to allege management fraud as a defense to a claim agaimst the accountants by the corporation that employed the managers. ${ }^{12}$ The court's opinion disregarded distinctions between traditional contract and tort law. ${ }^{13}$ Instead, Judge Posner focused on compensating the true victims

8. Although Judge Posner did not originate economic analysis of legal issues, he has become "its greatest popularizer and most vigorous proponent." Warren, Richard Posner Shakes up the Bench, AM. LAw., Sept. 1983, at 75-76; see also Schmalbeck, The Justice of Economics: An Analysis of Wealth Maximization as a Normative Goal, 83 ColuM. L. REv. 488, 524 n.133 (1983)(if others "may be said to have put economic analysis of the law on the map, Posner may be said to have built the super-highway connecting it with every major area of law"). For earlier proponents of economic analysis, see Coase, The Problem of Social Cost, 3 J. LAW \& EcoN. 1 (1960); Hardin, The Tragedy of the Commons, 162 SCLENCE 1243 (1968).

9. See infra notes $12-43$ and accompanying text.

10. See infra notes $44-77$ and accompanying text.

11. See infra notes $78-80$ and accompanying text.

12. 686 F.2d 449, 456 (7th Cir.), cert. denied, 103 S. Ct. 177 (1982).

13. The accountants in Cenco were sued for breach of contract, professional malpractice (negligence), and fraud. 686 F.2d at 453. Judge Posner cumbined the three legal theories into one analysis. See infra notes $27-32$ and accompanying text.

As Judge Posner implies, the formal distinctions between contract and tort analysis of accountant hability seem trivial. When an accountant performs an audit improperly, it essentially breaches its auditing contract and cummits a negligent tort.

Under a traditional contract analysis, courts would search the terms of the accountant's employment contract to decide whether the parties contemplated accountant responsibility. See, e.g., Southern Methodist Univ. v. United States, 645 F.2d 893, 900 (Ct. Cl. 1981); City of E. Grand Forks v. Steele, 121 Minn. 296, 299, 141 N.W. 181, 182 (1913); National Sur. Corp. v. Lybrand, 256 A.D. 226, 234, 9 N.Y.S.2d 554, 561 (1939). See generally Katsoris, supra note 6, at 197-98 (general discussion of accountants' contractual undertakings). Although the auditor and its client bargain at arms length, terms such as use of professional skill and care will be implied if not expressly included in the contract. See Gammel v. Ernst \& Ernst, 245 Minn. 249, 253-54, 72 N.W.2d 364, 367; Katsoris, supra note 6, at 192.

The analysis employed by courts as a basis for implying terms in the traditional contract parallels the standards found in the traditional tort analysis. Specifically, auditors liave a "duty" to perform with the skill and diligeuce of a reasonably prudent professional accountant. See 
of the fraud and on deterring future wrongdoing. ${ }^{14}$

Seidman \& Seidman is an independent auditing firm that was hired by Cenco. Cenco is a publicly held corporation that sold, among other things, medical supplies. Seidman's audit did not uncover a fraud perpetrated by several of Cenco's managers. ${ }^{15}$ These managers had fraudulently inflated inventories, enabling the company to maintam an artificially high stock price, to borrow at lower interest rates, to recover inflated insurance claims on lost or stolen inventory, and to buy up other companies "on the cheap." 16

After a newly-hired financial officer at Cenco discovered the fraud, thousands of its stockholders filed a federal class action ${ }^{17}$ against Cenco, its corrupt managers, and Seidman. ${ }^{18}$ Seidman and Cenco filed cross-claims against each other for indemnification of losses. ${ }^{19}$ Although both Seidman and Cenco settled with the class prior to litigation, ${ }^{20}$ the case proceeded to trial for resolution of the cross-claims.

The trial judge dismissed Seidman's cross-claim for damages

Katsoris, supra note 6, at 192. This duty requires "more than a rubber stamp for management." Bradley, Auditors' Liability and the Need for Increased Accounting Uniformity, 30 LaW \& CoNTEMP. ProBs. 898, 922 (1965); see also Herzfeld v. Laventhol, Krekstem, Horwath \& Horwath, 540 F.2d 27, 34 (2d Cir. 1976)(accountants must do more than verify the mathematical correctness of the bookkeeper's addition and subtraction).

Thus, under either theory the auditor has the same basic obligation. One important distinction is that third parties (those not a party to the contract) can sue in tort. See, e.g., Drake v. Thor Power Tool Co., 282 F. Supp. 94, 104 (N.D. Ill. 1967); Touche, Niven, Bailey \& Smart, 37 S.E.C. 629, 670 (1957); Duro Sportswear, Inc. v. Cogen, 131 N.Y.S.2d 20, 25 (Sup. Ct.), affd without opinion, 285 A.D. 867, 137 N.Y.S.2d 829 (1955). See generally Sonde, The Responsibility of Professionals Under the Federal Securities Laws-Some Observations, 68 Nw. U.L. Rev. 1, 3 (1973).

Allegations of fraud raise a distinction-culpability-that places analysis of that theory beyond the scope of this note. Judge Posner discussed this distinction only briefly, probably beeause "evidence that Seidman had knowledge of the fraud was imconclusive." In re Cenco, Inc. Sec. Litig., 519 F. Supp. 322, 327 (N.D. Ill. 1981).

14. A subsequent decision by the Seventh Circuit addressed this emphasis on compensation and deterrence, but distinguished Cenco and limited its application. See Schacht v. Brown, 711 F.2d 1343, 1348-49 (7th Cir.), cert. denied, 104 S. Ct. 508, 509 (1983); infra notes $58-67$ and accompanying text.

15. Cenco, 686 F.2d at 451.

16. Id. The fraud involved the Cenco Medical Health/Supply Corporation, a subsidiary in Cenco's Health Care Group. In re Seidman \& Seidman, SEC Accounting Release No. 196, [19371982 Transfer Binder Accounting Series Releases] FED. SEC. L. REP. (CCH) \ 72,218, at 62,521 (Sept. 1, 1976). Employees in this division inflated the value and extent of inventories by altering the quantities of inventory recorded on two-part, prenumbered inventory tags and the corresponding computer listings, and by creating new inventory tags to reflect the nonexistent inventory. $I d$.

17. The class consisted of the approximately 20,000-25,000 persons, Helfand v. Cenco, Inc., 80 F.R.D. 1, 6 (N.D. Ill. 1977), who lad purchased Cenco stock during a five-year span, Cenco, 686 F.2d at 455 .

18. Cenco, 686 F.2d at 451.

19. Id.

20. Seidman and Cenco paid $\$ 3.5$ million and $\$ 11$ million, respectively, to the shareholder class. Id. at $451,459$. 
against Cenco by issuing a directed verdict for Cenco on the claim. ${ }^{21}$ The judge submitted Cenco's cross-claims against Seidinan to the jury, ${ }^{22}$ instructimg that Seidman was entitled to assert the fraud of Cenco's inanagers as a defense against Cenco's charges of breach of contract, professional malpractice, and fraud. ${ }^{23}$ The jury found for Seidman on each of Cenco's claims. ${ }^{24}$

Cenco appealed to the Court of Appeals for the Seventh Circuit. 25 Judge Posner, writing for a unanimous panel, could find no authoritative statement of Illinois (the relevant state) law, ${ }^{26}$ and therefore applied his own interpretation of applicable common law standards. ${ }^{27}$ Judge Posner first combimed the legal principles of breach of contract, malpractice, and fraud into one analysis: "Despite the plurality of cliarges it is one question because [all of these causes of action], when committed by auditors, are a single forn of wrongdoing under different names." 28 Similarly, Judge Posner treated "the defenses based on misconduct of the audited firm or its employees . . . alike, though verbalized differently."29

In short, Judge Posner's Cenco opmion ignored traditional distinctions between common law causes of action and applied principles of deterrence and compensation to analyze accountant liability for undiscovered fraud. He used a two-pronged analysis to determine whether the inanagers' fraud should be imputed to the corporation..$^{30}$ First, he asked "whether a judgment in favor of the plaintiff corporation would
21. Id at $451-52$.
22. Id at 452 .
23. Id at 454 .
24. Id. at 452 .

25. Both sides appealed certain rulings. Id. at 452 . In addition, Cenco appealed froin the judgment against it (based on a jury verdict) and from the dismissal of two counts in its crossclaim. Id Seidman also appealed from the dismissal of its cross-claim. Id.

26. Judge Posner has been criticized for "flagrantly skirt[ing] precedent and unjustifiably impos[ing] free-market and economic-efficiency tests." See Warren, supra note 8, at 76.

27. Cenco, 686 F.2d at 452-53. The federal court had jurisdiction over Cenco's cross-claims, which were based on state law, through its ancillary jurisdiction. Id. The class action was properly brought in federal court, $i d$ at 451 , and the settlement was not approved until after the trial on the cross-claims had begun. Id. at 452 . Thus, although the issue had not been addressed by the Illinois courts, Judge Posner based his holding solely on an interpretation of Illinois state law. See id. at 454.

28. Id at 453.

29. Id Judge Posner observed that "breach of contract is excused if the promisee's hindrance or failure to cooperate prevented the promisor froin performing the contract." Id. Such conduct, according to Judge Posner, can also be viewed as contributory negligence. Id. He also explamed that "a participant in a fraud cannot also be a victim entitled to recover damages, for he cannot have relied on the truth of the fraudulent representations." Id at 454.

30. The Cenco court's analysis is explained in Scliacht v. Brown, 711 F.2d 1343, 1348-49 (7th Cir.), cert. denied, 104 S. Ct. 508, 509 (1983). For nore detailed discussious of Schacht, see infra notes 58-67, 77 and accompanying text. 
properly compensate the victims of the wrongdoing." 31 Second, he examined "whether such recovery would deter future wrongdoing." 32

\section{A. Deterring Management Fraud.}

Judge Posner mentioned at least four factors that led him to conclude that allowing the auditors to assert the inanagement fraud as a defense would deter such fraud. He briefly mentioned two of these factors: evidence that the innocent managers and shareholders of Cenco negligently failed to oversee internal control measures, ${ }^{33}$ and evidence that the auditors "diligently attempted to follow up all signs of fraud but had been thwarted" by the fraudulent managers. ${ }^{34}$ By allowing Seidman to assert this defense, Judge Posner apparently intended to deter further management fraud by placing a burden on "innocent" managers and large groups of shareholders to exercise some supervision over internal controls rather than relying solely on an independent auditor to uncover management fraud. Judge Posner also apparently reasoned that because the auditors "diligently attempted" to trace signs of fraud, forbidding them from asserting the defense would not promote deterrence of management fraud; a law that protects negligent unanagers while it penalizes diligent auditors would not deter management fraud.

Judge Posner also noted that the fraud in Cenco "permeate[d] the top managenent of the company." 35 He distinguished this type of fraud from that of "lowly" employees. ${ }^{36} \mathrm{He}$ apparently reasoned that deterrence objectives concerning low-level fraud might not be served

\footnotetext{
31. Id. (emphasis added).

32. Id. (emphasis added).

33. Judge Posner reasoned that

the honest owners, and their delegates-a board of directors on which dishonesty and carelessness were well represented - were slipshod in their oversight and so share responsibility for the fraud that Seidman also failed to detcet. In addition, the scale of the fraud - the number and high rank of the managers involved-both complicated the task of discovery for Seidman and makes the failure of oversight by Cenco's shareholders and board of directors harder to condone.
}

Cenco, 686 F.2d at 456.

34. Id. at 452 . This reasoning reflects the inajority position that auditors are insulated from absolute liability for failure to detect management fraud; audits are not specifically or primarily designed to uncover employee fraud. See 1 AICPA Professional STandards (CCH) AU $\$ 327.09$ (1977). In Judge Posner's more flowery prose, "[a]uditors are not detectives hired to ferret out fraud, but if they chance on signs of fraud they may not avert their eyes- they must investigate." Cenco, 686 F.2d at 454.

35. Cenco, 686 F.2d at 454.

36. Id. at 456. Judge Posner refused "to predict that the lllinois courts would hold that in any action by a corporation against its auditors an employee's fraud intended to benefit the company rather than the employee at the company's expense will be attributed to the corporation, however lowly the employee." Id. 
by holding the corporation responsible for extensive oversight of lowlevel employees. 37

Finally, Judge Posner emphasized that deterrence of management fraud would be furthered by holding the company responsible for oversight of managers only when the fraud benefited the company. He described "company benefiting fraud" as fraudulent activity for which outsiders to the corporation bear the primary costs, while the shareholders of the corporation are the "beneficiaries" of the fraud. ${ }^{38}$ Thus, because, in Judge Posner's view, the corporation was a beneficiary of the fraud, placing legal responsibility on it would deter corporations from purposely engaging in such fraud by offsetting the potential benefit to the corporation.

\section{B. Compensating Victims.}

As mentioned above, Judge Posner sought to assure that only the victims of the fraud would receive any damage awards. He noted, for example, that cases such as Cenco contain an inherent "potential mismatch between the recovery of damages by a corporation and the compensation of the shareholders actually injured by the wrong for which the damages were awarded." 39 In this case, however, he decided that the "mismatch" would be too great if Cenco could overcome Seidman's defense; a separate recovery for Cenco against its auditor would have unfairly compensated shareholders, who had already recovered dainages from both the auditor and the corporation through the class action settlement, and would also have compensated any corrupt managers who were still stockholders. ${ }^{40}$

After examining these deterrence and compensation considerations, Judge Posner concluded that Cenco could not "shift the entire cost of the fraud . . . to the independent auditor who failed to prevent the fraud." 41 He reasoned that "if the owners of the corrupt enterprise are allowed to shift the costs of its wrongdoing entirely to the auditor, their incentives to hire honest managers and monitor their behavior

37. On the other hand, it may be that employees "tend to accept the values of their company superiors. . . . [F]raud is perpetrated and the incentive to commit fraud is created in a climate of 'moral decay' that filters down from the top and permeates middle management." W. ALBRECHT, M. Romney, D. Cherrington, I. Payne \& A. Roe, How to Detect and Prevent Business Fraud 152 (1982)(citing Cenco Corporation as an example of the influence of dishonest management).

38. Cenco, 686 F.2d at 456.

39. Id. at 455; see also infra note 71 and accompanying text.

40. Cenco, 686 F.2d at 455.

41. Id. 
will be reduced."42 Accordingly, Judge Posner decided to impose liability on the "owners of the corrupt enterprise" rather than on the auditor, even though the auditor could have been "more diligent and honest."43

\section{Rethinking CENCO's Economic AnAlysis}

Judge Posner's basic approach in Cenco appears to be correct; few would dispute the importance of deterring management fraud or of compensating only the victims of such fraud. Unfortunately, the opinion fails adequately to address many arguments, and it indulges in conclusory reasoning that does not withstand detailed analysis. Although Judge Posner's basic approach may be sound, ${ }^{44}$ two of the four factors

42. Id. Judge Posner ignored the other incentives to hire honest managers. In his book Economic Analysis of Law, Judge Posner discusses shareholder incentives to monitor management behavior. R. POSNER, ECONOMIC ANALYSIS OF LAW 302-04 (2d ed. 1977). He suggests that profit maximization is the primary incentive for shareholders to monitor management. $/ d$. at 303 . Moreover, conflicts of interest between management and shareholders usually cause the latter to insist upon protective features in the corporate charter. $/ d$. at 302.

According to Judge Posner, the price of the firm's common stock will fall when management disregards the interests of shareholders, which will then result in exploitation by "alert investors" with the knowledge that the stock is underpriced. $/ d$. at 303 . The methods of oustimg management-the tender offer, the proxy fight, and voluntary acquisition-demonstrate the difficulty of shareholder action in instances of mismanagement. See id. at 304. The problem with these avenues of shareholder control is noted by Judge Posner himself: "for most shareholders the opportunity costs of active participation in the management of the firm would be prohibitively high." Id. at 303.

Thus, shareholders have a pecuniary interest in preventing all forms of mismanagement, including fraud. Although fraud may temporarily benefit the corporation, the cost of nismanagement is ultimately "borne by the original shareholders in the form of a dilution of their interest." See id. at 302.

In addition, there are shareholders who, for either moral or ethical reasons, desire to have honest managers because they do not wish to be associated with a dishonest corporation. Many shareholders behieve that a corporation has social responsibilities apart from the goal of profit maximization. See id. at 310-11.

43. Id.

44. For example, the distinction between upper- and lower-echelon employees may be a legitimate one. As one moves down the operational scale of responsibility in a typical corporation, employees naturally divide into functional subgroups with "subgoals." Stone, Social Control of Corporate Behavior, in Corporate and Governmental Deviance: Problems of Organizational Behavior in Contemporary SOciety 243, 252 (M.D. Ermann \& R. Lundman eds. 1978). The tasks of the smaller groups are more likely to be specific, with minimal emphasis on "corporate profit" in the abstract. Jd.

The internal fiow of information normally operates to prevent evidence of wrongdoing from reaching top managemeut. Id. at 253. Moreover, even if information reaches the management level, it is often effectively "screened." Id. Bad news often does not reach the top because employees are concerned, to varying degrees, with either displeasing or tarmishing the reputation of the corporation's nranagement. Id.

It follows that auditors would be expected to discover financial fraud by lower echelon employees; otherwise, the information may never reach management, the individuals who are in the best position to correct the situation. See id. It is a different situation, however, when manage- 
that he considered when analyzing deterrence-the duty to monitor and "beneficial" fraud-seem to support a contrary result in Cenco. Moreover, Judge Posner's "compensation analysis" is unconvincing.

\section{A. The Duty to Monitor.}

Judge Posner's assertion that the innocent inanagers and the large group of shareholders improperly failed to monitor the guilty managers contains at least two flaws. Judge Posner reveals one of these flaws in his book, Economic Analysis of the Law:

The typical shareholder (except . . . where one shareholder owns a very large percentage of the shares ... .) is not knowledgeable ... and neither expects nor has an incentive to participate in the management of the firm. He is a passive investor and, because of the liquidity of his interest, has only a casual and frequently quite transitory relationship with the firm. His interest like that of a creditor is a financial rather than managerial interest. In a technical sense the shareholders "own" the corporation but they do not own it in the same sense in which they own their own automobiles; it would be better to speak of their owning the common stock of the corporation. ${ }^{45}$

Given this statement, one is surprised to find the following language in Cenco: "Cenco's owners-the stockholders-hired managers . . . who turned out to be thoroughly corrupt. . . . [I]f the owners of the corrupt enterprise are allowed to shift the costs of its wrongdoing entirely to the auditor, their incentives to hire honest managers and monitor their behavior will be reduced."46

Surprisimgly, then, the "passive owners" of Cenco suddenly acquire a duty to actively monitor the management-an activity in which

ment participates or acquiesces in fraudulent conduct. Then, those who should oversee the behavior of others are placed in a position of policing their own fraudulent conduct.

A corollary concern is that threats to the corporate treasury do not necessarily constrain key personnel from engaging in illegal or fraudulent behavior. See id. at 254 . There is "no reason blithely to suppose that a threat reasonably calculated to make lawbreaking a poor bargain for 'the corporation' will change management's calculations in the direction society desires." Id. at 258. To the extent, however, that

the most imfluential managers of the corporation are not just salaried, but also holders of common shares, or of option plans to purchase shares, their personal calculations fall more in line with those of the shareholders. Even then, however, it does not follow that there is a "unity" of their interests and the interests of "the corporation" (referring to some mix of interest of common shareholders, creditors, employees and bondholders).

Id. at 256 .

45. R. POSNER, supra note 42 , at 301 .

46. Cenco, 686 F.2d at 455 (emphasis added). Judge Posner continues:

While it is true that in a publicly held corporation such as Cenco most shareholders do not have a large enough stake to play an active role in hiring and supervising managers, the shareholders delegate this role to a board of directors, which in this case failed in its responsibility.

Id. at $455-56$. 
they have no "incentive to participate." This interpretation of the shareholders' monitoring responsibilities, however, is less reasonable than Judge Posner's earlier analysis in his book. Expecting passive shareholders to inonitor corporate managers to the extent necessary to uncover inanagement fraud is unrealistic.

Even if the innocent managers and shareholders have a duty to inonitor corrupt managers, the duty should be inet when the corporation hires independent accountants to conduct an audit. These auditors are not expected to "ferret out fraud," but conformance to Generally Accepted Auditing Standards (GAAS) ${ }^{47}$ does require "proper study

47. Generally accepted auditing standards define the level of quality of the auditing procedures. One of the standards requires the auditor's report to state whether the financial statements were performed according to Generally Accepted Accounting Principles (GAAP). See Fiflas, Current Problems of Accountants' Responsibilities to Third Parties, 28 VAND. L. REv. 31, 40 (1975). "Generally accepted" is somewhat misleading when used to describe accounting principles because custoinary practices are only one category of GAAP. GAAP also includes dependable business practices, views of regulatory agencies (especially the SEC), bankers, and stock exclanges, academic opinions, and opinions of the American Institute of Certifled Public Accountants (AICPA). Id. at 41.

Auditing procedures, unlike auditing standards, vary from one set of circuinstances to another. Levitin, Accountants' Scope of Liability for Defective Financial Reports, 15 Hastinos L.J. 436, 438 (1964).

The Standards of Field Work, as established by the AICPA, provide in part:

[1] ... The examination is to be perforned by a person or persons having adequate technical training and proficiency as an auditor.

[2] In all matters relating to the assignment, an independence in mental attitude is to be maintained by the auditor or auditors.

....

[3] Due professional care is to be exercised in the perfonnance of the examination and the preparation of the report.

1 AICPA Professional Standards (CCH) AU $\$$ 210.01, 220.01, 230.01 (1972).

Standards of Field Work are:

[1] ... The work is to be adequately planned and assistants, if any, are to be properly supervised.

...

[2] There is to be a proper study and evaluation of the existing internal control as a basis for reliance thereon and for the determination of the resultant extent of the tests to which auditing procedures are to be restricted.

[3] Sufficient competent evidential matter is to be obtained through inspection, observation, inquiries, and confirmations to afford a reasonable basis for an opinion regardimg the financial statements under examination.

Id. $\$ \$ 311.01$ (1978), 320.01 (1972), 326.01 (1980).

Standards of Reporting include:

[1] . . . The report shall state whether the financial statements are presented in accordance with generally accepted accounting principles.

…

[2] The report shall state whether such principles lave been consistently observed in the current period in relation to the preceding period.

[3] Informative disclosures in the financial statements are to be regarded as reasonably adequate unless otherwise stated in the report.

.... 
and evaluation of . . . existing internal control."48 Thus, an independent auditor serves any supervisory function that could be expected of the "passive owners" of a publicly lield corporation. ${ }^{49}$

Moreover, the duty Judge Posner would impose would create inefficiency. First, Judge Posner would apparently require sliareholders with as little as five percent of a company's stock to hire their own auditors. ${ }^{50}$ Second, he would apparently require groups of shareholders and innocent managers to do more than hire their own independent auditors: "large" shareholders must adopt measures in addition to au-

[4] The report shall either contain an expression of opinion regarding the financial statements, taken as a whole, or an assertion to the effect that an opinion cannot be expressed. When an overall opinion cannot be expressed, the reasons therefor should be stated. In all cases where an auditor's name is associated with financial statements, the report should contain a clear-cut indication of the character of the auditor's examination, if any, and the degree of responsibility he is taking.

Id. $\S \S 410.01$ (1972), 420.01 (1972), 431.01 (1980), 504.01 (1979)(emphasis added).

48. See id. $\$ 327.09$ (1977). The audit is intended to close the credibility gap that would result if there were no independent investigation of the financial stateinent prepared by corporate management. See id. $\$ \$ 110.01,110.02,220.01,220.02,220.03,220.04,220.07$ (1972). The objective of the audit is to express an opinion on whether a corporation's financial statements fairly represent its financial condition and operating results. Id. $\S 110.01$ (1972). The information in the financial statements and accounts reflect matters within the knowledge and control of management. Id. $\S 110.02$ (1972). Manageinent is responsible "for adopting sound accounting policies, for maintaining an adequate and effective system of accounts for the safeguarding of assets, and for devising a system of internal control that will, among other things, help assure the production of proper financial statements." Id.

The auditor must be independent of management, id. $\S 220.02$ (1972), and inust conduct a study and evaluation of internal control, id. $\$ 320.01$ (1972). Internal control is examined to determine the extent to which the information supplied can be relied upon in determining the nature, extent, and tining of the audit tests to be utilized in the examination of the financial statements. Id. $\$ 320.06$ (1972); see also supra note 4 (discussion of management's mampulation of internal controls).

49. In fact, investors are not in a position to monitor or supervise management's actions:

The control of [a] firm resides in a management group . . . [consisting] of people who are experienced in the business and involved in it on a full-time, day-to-day basis. The typical shareholder ... is not knowledgeable about the business of the firm, does not derive an important part of his livelihood from it, and neither expects nor has an incentive to participate in the inanagement of the firm. . . . His interest like that of a creditor is a financial rather than managerial interest.

R. POSNER, supra note 42, at 301. According to Judge Posner, shareholders own "their" corporation only in a technical seuse: "they do not own it in the same sense in whicll they own their automobiles; it would be better to speak of their owning the common stock of the corporation." Id. Furthermore, Judge Posner does not find it anomalous that slareholders do not manage or control "their" corporation. Id.

Because shareholders neither monitor nor nanage a corporation effectively, the audit has come to serve an increasingly inuportant function for shareholders, creditors, and others. For a discussion of the evolution of the audit function "from a mere watchdog for management to an independent evaluation of the adequacy and fairness of financial statements issued by management" to third parties, see Comment, Auditors' Responsibility for Misrepresentation: Inadequate Protection for Users of Financial Statements, 44 WASH. L. REV. 139, 178 (1968).

50. See Cenco, 686 F.2d at 456. 
dits to momitor the corporation's management. ${ }^{51}$ Moreover, each group of shareholders and each manager would be making similar, and therefore duphicative, examinations of management.

\section{B. The Beneficial Fraud Distinction.}

Judge Posner also justified his result in Cenco by arguing that deterrence of beneficial fraud-as opposed to detrimental fraud-would be achieved more efficiently by imposing liability on the corporation. He appeared to define beneficial fraud as fraud for which "the primary costs . . . are borne not by the stockholders but by outsiders to the corporation."52 Thus, according to Judge Posner, deterrence of such fraud must be achieved in a different fashion than deterrence of detriinental fraud-fraud in which the corporation bears the primary costs. ${ }^{53}$ The beneficial/detrimental distinction is not sound given Cenco's emphasis on deterrence; the distimction has no relevance-and Judge Posner supplies none-to affecting the behavior of either the fraudulent managers, the innocent managers, or the shareholders. ${ }^{54}$

The fraudulent managers are not affected by a distinction based on which party-the corporation or the auditor-bears the primary cost of the fraud. Any costs imposed on a corporation by detrimental fraud that are absent in instances of beneficial fraud will not affect managers' behavior; the corporation, not the managers, absorbs such costs. More-

51. Curtis-Wright Corporation, which owned 5\% to $16 \%$ of Cenco's common stock while the fraud was being committed, had its own accounting firm conduct "a study of Cenco's operations." Id. These auditors also failed to uncover the fraud. Id.

52. Cenco, 686 F.2d at 456.

53. Id. "Detrimental" fraud would occur, for example, if the managers of a corporation sold a secret trade formula to competitors. Even if the sale went undetected for a period of time, the corporation would bear the primary cost. Moreover, even if damages were recovered and criminal sanctions imposed, nothing could replace the loss of prestige and exclusivity enjoyed by the corporation.

54. In fact, it is unclear whether any fraud ultimately benefits a corporation. Even Judge Posner admitted that Cenco may not be a "net beneficiary" of the fraud "after the fraud is unmasked and the corporation is sued." Cenco, 686 F.2d at 456 . He avoided the issue by stating: "that is a question of damages, and is not before us." Id. Nevertheless, Cenco had already contributed \$1l million to the settlement, id. at 459, and had undoubtedly suffered loss of goodwill because of the suit's effect on its reputation. As a passage by Posner suggests, shareholders ultimately bear the loss of a management fraud:

The danger of mismanagement is less serious than the danger that the managers will not deal fairly with the shareholders. Mismanagement will lead eventually to the bankruptcy of the firm. . . The managers thus have a strong imcentive to manage the firm well or, if they are unable to manage it well themselves, to sell their offices to those who can. The incentive to deal fairly with shareholders is weaker. To be sure, managers who do not deal fairly with the shareholders will have to pay a premium should they ever want to raise additional capital. . . . But the cost of the premium will not be borne by the managers; it will be borne by the original shareholders in the form of a dilution of their imterest. There is thus [a] potential conflict of interest . . . .

R. POSNER, supra note 42 , at 302. 
over, the innocent managers and shareholders will not be encouraged to adopt monitoring measures designed solely to detect beneficial fraud; designing such measures would be impractical, if not impossible. ${ }^{55}$

The steps that would have been necessary to detect the fraud in Cenco illustrate this point. Cenco's guilty managers inflated the inventory figures. ${ }^{56}$ To detect this inflation, Cenco needed internal controls that monitored inventories more closely than did the controls used at the time of the fraud. Specifically, it needed controls that monitored the personnel in charge of inventory. ${ }^{57}$ Such controls would undoubtedly be designed to detect both imventory undervaluation and theft, as well as inventory inflation. Only after the fraud had been detected would Cenco have known whether it was beneficial or detrimental. In short, given Judge Posner's desire to deter management fraud before it occurs, focusing on "beneficial fraud" is not helpful.

A subsequent opinion by the Seventh Circuit, Schacht v. Brown, ${ }^{58}$ accentuates the difficulty in distinguishing between detrimental and beneficial fraud. In Schacht, accountants and managers concealed the fact that a corporation was insolvent. ${ }^{59}$ This allowed the corporation to remaim active; the state would have forbidden the corporation from writimg insurance-its primary busmess activity-if it had known of the imsolvency. ${ }^{60}$ Because the corporation remained active, its customers, creditors, and even its parent corporation suffered damage. ${ }^{61}$

A panel of the Court of Appeals for the Seventh Circuit that did

55. The difficulties of developing such monitoring measures become apparent after an examination of Cenco's procedures. See In re Seidman \& Seidman, SEC Accounting Release No. 196, [1937-1982 Transfer Binder Accounting Series Releases] FED. SEC. L. REP. (CCH) I 72,218, at 62,520 (Sept. 1, 1976); see also supra note 16; infra note 56.

56. The managers inflated inventories by overstating the number of items in the inventory. Cenco's personnel used two-part tags when calculating inventory tags. Id. at 62,521. Used, unused, and voided tags were processed onto computer cards from which the inventory lists were made. Id. But Cenco personnel reported nonexisteut inventory. See id. at 62,522-23.

These inflated inventories accounted for 34\% of Cenco's total assets in 1974. Id. at 62,523. And of the $\$ 39$ million in assets reported by Cenco Medical Health/Supply Corporation, about $50 \%$ of it was nonexistent. Id.

57. See supra notes 55-56.

58. 711 F.2d 1343 (7th Cir.), cert. denied, 104 S. Ct. 508, 509 (1983).

59. In Schacht a statutory hquidator charged, inter alia, that accountants knew of the insolvency of an insurance company, but prepared unqualified opinion letters on the company's financial statements. 711 F.2d at 1345. The parent corporation of the insurance company "laundered" the latter's insufficient surplus by funneling some of its high-risk insurance business to another subsidiary. Id.

60. The Illinois Department of Insurance failed to discover the insolvent subsidiary's inadequate supphies and approved the company's continuation provided certain surplus requirements were met. Id.

61. See id. at 1350. 
not include Judge Posner ${ }^{62}$ explained why Cenco did not apply to Schacht. Judge Wood, who also sat on the Cenco panel and who wrote the opinion in Schacht, focused on the "beneficial fraud" factor. ${ }^{63}$ But the Schacht court adopted the approach rejected by Posner in Cenco; it focused on whether the corporation was a "net beneficiary" of the fraud. Finding that the fraud was not beneficial to the corporation, the court reasoned that "the fact that . . . [the corporation's] existence may have been artificially prolonged pales in comparison with the real damage allegedly inflicted by the dininution of its assets and income." 64

The court's approach in Schacht contradicts and ignores Judge Posner's reasoning in Cenco. As inentioned above, Judge Posner focused on whether third parties or the corporation incurred the initial primary costs of the fraud; he was unwilling to look at the long-term "real damage" to the corporation. ${ }^{65}$ Under the reasoning in Cenco, Judge Posner would have found the fraud in Schacht to be beneficial to the corporation, a pivotal factor militating in favor of allowing the auditor's defense in Cenco ${ }^{66}$ Thcse divergent results are not as important as the ramifications Schacht has on the validity of distinguisling between beneficial and detrimental fraud. ${ }^{67}$ Judge Wood's failure to analyze beneficial fraud in the same inanner as Judge Posner's Cenco opimon, an opinion in whicll Judge Wood joined, underscores the irrelevance of any beneficial/detrimental distinction.

62. The panel consisted of Chief Judge Cummings, Judge Wood, and Judge Walter Hoffman, Serior District Judge of the Eastern District of Virginia, who sat by designation. Id. at 1344 . Judge Wood wrote the opinion.

63. The Schacht court essentially limited Cenco's holding to its facts. It reasoned that the defense of management fraud could not be invoked unless the fraud benefited the chent. $I d$. at 1347-48. In other words, Cenco's holding does not apply when the client is a victim, rather than a beneficiary, of the fraud.

64. Id. at 1348.

65. See supra note 38 and accompanying text.

66. In Schacht, the fraudulent scheine had the effect of extending the corporation's existence beyond the poimt of imsolvency. See Schacht, 711 F.2d at 1348. As the court in Schacht points out, however, "the fact that [the corporation's] existence may have been artificially prolonged pales in comparison with the real damage allegedly imflicted by the diminution of its assets and income." Id. Apparently, the prolongation benefited the inanagers and the other alleged conspirators, but not the corporation. Id.

The court in Schacht takes the step that Judge Posner declmed to consider in Cenco: evaluating the "net" effect of the fraud. See Cenco, 686 F.2d at 456 . Under the Cenco analysis, those who prolonged the life of the corporation in Schacht would be committing frand "on behalf of" the corporation, see id, and, therefore, the corporation would beneflt from the fraud.

67. The court's failure to extend Cenco to the facts of Schacht is of some significance; it could have decided to extend use of the Cenco defense to factual contexts not involving "beneficial fraud." The court admitted, for exaunple, that it was writing "on a clean slate." Schacht, 711 F.2d at 1347. It could have therefore adopted Judge Posner's reasoning in Schacht; Judge Posner had also written "on a clean slate" in Cenco. See Cenco, 686 F.2d at 454; supro note 26 and accompanying text. 


\section{The Compensation Analysis in Cenco.}

Judge Posner also based his holding in Cenco on his belief that a judginent for Cenco would be "perverse from the standpoint of compensating victims of the wrongdoing.". 68 The judgment would be "perverse" because the corrupt managers and undeserving shareholders would be improperly compensated. 69 As with the distinction between beneficial and detrimental fraud, ${ }^{70}$ lowever, the Cenco opinion and the Schacht opinion illustrate the immateriality of this factor.

Assuring that damage awards to corporations reach deserving shareholders is a constant problem because of the transitory nature of stock ownership. ${ }^{11}$ Cenco shareholders at the time of the decision, for example, may have included speculators who bought the stock anticipating a recovery from Seidman. Such speculatimg shareholders undoubtedly abound, and they are frequently coinpensated notwithstanding the fact that they were not true victims of the damage to the corporation.

Moreover, if the goal of not compensating the guilty managers or the shareholders who have already recovered is of paramount importance, a court could structure its reinedy to preclude such compensation. ${ }^{72}$ Judge Posner could, for example, have constructed a remedy in equity that specifically precluded damage payments to any guilty managers owning Cenco stock and any shareholders who had recovered through the settlement. But he did not even mention evidence that any of the alleged "improper compensation" would occur. Instead, he merely stated that "[t]o the extent that [the corrupt managers] are still stockholders in the company, they would benefit pro rata from a judgment in favor of Cenco."73 By basing his decision on sucli hypothetical evidence of potential mismatched compensation, Judge Posner detracts from deterrence of management fraud-the goal he vehemently pursues in the rest of the opinion. ${ }^{74}$

68. Cenco, 686 F.2d at 455.

69. See supra notes $31,39-40$ and accompanying text.

70. See supra notes $52-67$ and accoinpanying text.

71. For example, in a class action derivative suit, the court approved portions of a settlement to recover illegal corporate campaign donations in 1978, six years after the donations were inade, and three years after the suit was instituted. See Shlensky v. Dorsey, 574 F.2d 131, 135-39 (3d Cir. 1978). Although recoveries in derivative suits are sought for the benefit of the corporation, see id. at 147 , shareholders of record benefit indirectly, see id. at 148. In most corporations the shareholders of record fluctuate constantly.

72. Courts considering derivative actions brought by minority shareholders have constructed remedies to fit the circumstances of the case. See, e.g., Perlman v. Feldman, 219 F.2d 173, 178 (2d Cir. 1954), cert. denied, 349 U.S. 952 (1955).

73. Cenco, 686 F.2d at 455 .

74. See supra notes 32-34 and accoinpanying text. 
Altering Cenco's facts illustrates this point. Instead of assuming that Seidman audited Cenco diligently, assume, as the SEC eventually found, ${ }^{75}$ that Seidman did not follow GAAS during its audit. If it could be demonstrated that the fraud would have been discovered but for Seidman's negligence, it would be difficult to absolve Seidman of liability, notwithstanding the "potential misinatch between the recovery of damages by a corporation and the compensation of the shareholders actually injured by the wrong for which the damages were awarded."76 Emphasizing "mismatches" in compensation awards serves little purpose in cases in which a corporation recovers damages; the remedy can always be structured to avoid truly "perverse" compensation.

Dictum in Schacht provides a final illustration of the flaws in emphasizing potential "perverse" coinpensation. In Schacht the court ream soned that, in contrast to Cenco, "the other actions noted to this court based on these alleged events have yet to result in any recovery."77 This reasoning implies that the results of a case like Cenco could depend entirely and fortuitously on which of several claims is resolved first, an unreliable and unacceptable way to render a principled decision.

\section{CONCLUSION}

In Cenco, Judge Posner purported to promulgate a doctrine that would deter management fraud. To be of any value, Judge Posner's doctrine should deter improper actions taken by at least one of three parties: large shareholders, the innocent managers, or the auditor. Unfortunately, the factors that he found determinative have minimal practical relevance to such deterrence.

First, distimguishing fraud that "benefits" the corporation in its mitial stages has little deterrent effect on any party. Second, any problems with unwarranted compensation can be easily avoided by tailoring the

75. See In re Seidman \& Seidman, SEC Accounting Release No. 196, [1937-1982 Transfer Binder Accounting Series Releases] FED. SEC. L. REP. (CCH) \ 72,218, at 62,520 (Sept. 1, 1976).

76. Cenco, 686 F.2d at 455.

77. Schacht, 711 F.2d at 1349. The Schacht court supplied another reason:

any recovery by the Director from the instant suit will inure to Reserve's estate. And under the distribution provisions of the governing liquidation statute, it is the policylolders and creditors who lave first claim. . . . Thus, the claims of these entirely innocent parties inust be satisfied in full before Reserve's shareholders, last in line for recovery, receive anything.

Id. at 1348. The court admitted, however, that it could not "speculate on the existence or relative size of any recovery to Reserve's sharelolders." Id. at 1349 n.5. Because the fraud was extensive and lasted approximately five years, prior claims may exhaust the estate before the sliareholders are allowed to participate in the recovery. 
remedy to preclude such compensation. Arguably, placing responsibility on the corporation for some undetected management fraud may provide shareholders and managers with an incentive to escalate monitoring of management, but primary responsibility for such monitoring must remain with the auditors.

Surprisingly, however, Judge Posner did not scrutinize closely the auditor's actions in Cenco. Judge Posner's opinion inconsistently described the auditor's actions as "diligent"78 and as requiring nore diligence and honesty; ${ }^{79}$ a subsequent SEC investigation revealed Seidman's failure to comply with GAAS in its audit. ${ }^{80}$ Arguably, corporations should be solely responsible for undetected management fraud in extreme cases. But before refining nuances of incentives for companies to inonitor themselves, the law must ensure that professionals hired by the companies for such monitoring fulfill their obligations. The approach taken by Judge Posner, and the result in Cenco, do not promote this goal.

Cathy A. Gay

78. See Ceneo, 686 F.2d at 452.

79. Id. at 455 .

80. See supra note 75. For examples of the weight given to compliance with professional standards, see United States v. Simon, 425 F.2d 796, 806 (2nd Cir. 1969), cert. denied, 397 U.S. 1006 (1970)(expert testimony is inconclusive as to compliance with GAAS when testimony dealt with the accountants" "honest judgment" rather than specific rules); Herzfeld v. Laventhol, Krekstein, Horwath \& Horwath, 378 F. Supp. 112, 125 (S.D.N.Y. 1974)(accountants complied with GAAP but recovery under Rule 10b-5 allowed), aff d in part and rev'd in part, $540 \mathrm{~F} .2 \mathrm{~d} 27$ (2d Cir. 1976); Escott v. BarChris Constr. Corp., 283 F. Supp. 643, 658-59 (S.D.N.Y. 1968)(court made no reference to accounting profession's standards but leeld as a matter of law that the disputed report of gain was misleading); Fischer v. Kletz, 266 F. Supp. 180, 188-89 (S.D.N.Y. 1967)(court fashions its own auditing standard); In re Haskins \& Sells and Andrew Stewart, SEC Accounting Release No. 73, [1937-1982 Transfer Bimder Accounting Series Releases] FED. SEC. L. REP. (CCH) I 72,092, at 62,196 (1952)(SEC uses its own judgment as to what constitutes sound accounting practice); Interstate Hosiery Mills, Inc., 4 S.E.C. 706, 715 (1939)(SEC demes sufficiency of the "usual practices" followed by accountants as the test of liability although testimony of expert accountants "relevant and helpful"); Stanley L. Bloch, Inc. v. Klem, 45 Misc. 2d 1054, 1057, 258 N.Y.S.2d 501, 506 (Sup. Ct. 1965)(failure to comply with GAAS results in liability under tort or contract theories). 